\title{
Benefits of a Marketing Cooperative in Transition Agriculture: Mórakert Purchasing and Service Co-operative ${ }^{1}$
}

\author{
Zoltán Bakucs \\ Research fellow, Research Centre for Economic and Regional Studies of the Hungarian \\ Academy of Sciences \\ Corvinus University of Budapest \\ Email: bakucs@econ.core.hu \\ Imre Fertő \\ Research advisor, Research Centre for Economic and Regional Studies of the Hungarian \\ Academy of Sciences \\ Professor, Corvinus University of Budapest
}

\begin{abstract}
Gábor G. Szabó
Senior research fellow, Research Centre for Economic and Regional Studies of the Hungarian Academy of Sciences
\end{abstract}

\begin{abstract}
The paper analyses the potential benefits of marketing cooperatives in Hungary, employing a transaction cost economics framework. We found that the purchased quantity, the existence of contracts, flexibility and trust are the most important factors farmers consider when selling their products via a cooperative. The most striking result is that diversification has positive influences on the share of cooperatives in farmers' sale. Furthermore, farmers with larger bargaining power have less willingness to sell their product to the cooperative. Surprisingly, asset specificity has rather negative effects on the share of cooperatives in members' sales.
\end{abstract}

\footnotetext{
${ }^{1}$ The research was supported by OTKA (grant number K68467) and by the Bolyai János Scholarship.
} 
Keywords: contract enforcement, co-operative, transition economy, Tobit model

JEL codes: C12, C25, D23

\section{Introduction}

The agricultural sector in transition countries can be described by considerable uncertainties. In these countries public institutions are ineffective in ensuring contract enforcement. The absence of enforceable contracts has made setting up any kind of vertical co-ordination difficult. In addition, this creates severe barriers for price discovery involving high transaction costs to coordinate market exchanges. In those sub-sectors, where any type of production contracts do exist, agricultural producers face hold-up problems (e.g. delayed payment for delivered products or ex-post price reduction by retailers). These phenomena are reinforced by the emergence of the modern retailing sector, leading to serious problems for subsectors dominated by fragmented and small-scale farms, e.g. the horticultural sector. Recently there is a growing literature focusing on various governance structures of agriculture in the transition countries employing different frameworks (e.g. Gow et al., 2000, Dries - Swinnen, 2004, Gorton et al. 2006). Furthermore other papers concentrate on the role of contracts in transition agriculture (Boger 2001; Beckmann - Boger 2004). Although there is a wealth of literature on producer cooperatives in transition countries (Gardner - Lerman 2006), but research on the role of marketing cooperatives in transition agriculture is scarce. Some relevant papers include Forgács (2008), discussing the importance of leadership of cooperatives during transition, through the example of two successful, yet very different Hungarian cooperatives (Béke co-op, a traditional one, founded in 1955 and Hajdú Gazdák Purchasing and Marketing co-op, operating in its present form since 1999) located in the same town. The paper concludes that the more social oriented leadership helped the survival of the traditional co-op, whilst the success of the second one depends mostly on the accumulated social capital after the radical reforms of the 1990s. Hanf and Török (2009) used the example of Mórakert co-op in their paper focusing on the integration of small farmers into supply chains. The authors discuss the supply chain network challenges agricultural producers face, and the possible solutions various types of co-ops can offer.

This paper tries to contribute to Central and Eastern European literature focusing on the benefits and roles co-ops may play in the rapidly changing supply chain management issues. 
Marketing cooperatives may solve some problems of vertical coordination; however the number of cooperatives is still limited in Hungary. In this study, we examine Mórakert Purchasing and Service Co-operative, in Mórahalom, county Csongrád, which is located in the South-Eastern part of Hungary. With increasing annual turnover and membership, Mórakert was a successful co-operative, a good example for solving various coordination issues in the Hungarian horticultural sector within an evolving supply chain.

The aim of the paper is to identify the costs and benefits of co-operative membership and their explanatory factors using a small-scale survey among co-op members. The remainder of the study is organised as follows. Section 2 provides a brief overview on the development of Mórakert cooperative. Section 3 reviews the theoretical background. The survey design and the variables are described in section 4 and results are presented in section 5 . The last section summarises the paper and offers some conclusions on the implications for the market mechanisms of Hungary's horticultural sector.

\section{Development of Mórakert cooperative}

In this section we provide a brief description of the development of the Mórakert Purchasing and Service Co-operative. The Mórakert co-operative was active in the fruit and vegetable sector and it was the first officially acknowledged Producers' Organisation (PO) in Hungary, certified in 2002. It worked as a very successful co-operative (e.g. in terms of increasing annual turnover and membership), thus being a good example for a number of emerging producer organisations.

In 1993 the Department for Agriculture was established within Mórahalom's municipality in order to help small-holders to submit application forms for various calls for proposals. The main incentive for establishing a co-operative was very similar to the Danish tradition: economic necessity, arising from the economic and market situation at the beginning of the 1990s. Therefore, as a first step, an organisation was established to build up countervailing power, provide information to farmers and strengthen their negotiation power the against retailing and processing industries.

The next step was made in January 1994 by establishing the Common Agricultural and Entrepreneurial Society, Mórahalom, as a non-profit organisation, with the aim of organizing 
small-holders within a loose network. There were 35 founding members of the Society. Besides organising and managing joint projects, one of the main activities was the coordination of collective purchasing activities. This type of co-ordination was successful, and in some cases savings up to 18-20 percent of the purchase cost were achieved.

These joint purchasing activities were extremely successful in decreasing transaction costs, e.g. information, negotiation and transportation costs (TCs). However, the main problem this organisation could not cope with, was the coordination of the marketing of the small-holders' produce. Therefore, the next step was to set up the Mórakert Purchasing and Service Cooperative, Mórahalom in April 1995.

About 90 per cent of the products distributed on domestic markets by the co-operative were sold to retail chains (Tesco Global, Auchan Hungary, Csemege-Match, SPAR Hungary, PROFI Hungary, CORA, CBA etc.). In the first few years of the co-op's existence the share of the retail chains was only about $5-10 \%$ of total sales. In the period between 1997-1999 this had increased to 90 per cent. To be able to increase the value of the members' products, the co-operative sought export opportunities. 80 percent of the produce purchased from members was sold on the domestic market and 20 percent abroad (Estonia, Latvia, Lithuania, The Czech Republic, Slovakia, Slovenia).

The co-operative paid great attention to the quality and homogeneity of their products, whilst trying to assure a versatile assortment in order to fulfil the retail chain's requirements. The co-op occasionally bought products on spot markets and sometimes from import too. First the products of the members were sold by the co-op, then, if needed, they called for the produce of non-member suppliers, and finally - to fulfil the requirements of the consumers (e.g. retail chains) - imported products.

One of the main steps to improve the competitiveness on segmented markets was to differentiate the products from those of other producers. The co-operative integrated both horizontally and vertically the members' farming activities, and started to focus on higher added value activities. The co-operative had a site equipped with full infrastructure. The handling, sorting and packaging line for vegetables and fruit was put into operation in September 1999. In 2002 a so-called "Agri-logistics Center" was set up by the co-operative 
that covered $4,000 \mathrm{~m}^{2}$ including a cold storage depot, covering $1 / 4$ of the total area. These investments were crucial to fulfil the food safety, environmental and hygiene requirements of the European Union. The third phase of development was the enlargement of the Agrilogistics Center with a 6,000 $\mathrm{m}^{2}$ storage facility. By June 2006 the co-op was using 15,000 $\mathrm{m}^{2}$ of storage facility. The facilities were fitted with modern sorting and packaging lines, enabling the co-op to export up to $20 \%$ of its products. Thus all operations (such as purchasing, handling, sorting and packaging of products originating from members and other suppliers, as well as the storage and transportation activities) were performed in one place. A computer supported information system helped the work in the new headquarters.

The main aims of the co-operative were as follows: help farmers to sell their horticultural products, purchase input materials on behalf of the co-op members at the most favourable prices, and offer long term security. The co-operative extended its membership and circle of suppliers during the period between 1995 and 2007 and tried to involve more segments of the fruit and vegetable chain. The increase in both membership and the turnover of the cooperative demonstrates that the co-op was operating efficiently during that period.

The total net revenue of Mórakert co-op reached HUF 8 billion in 2007, a very significant result for the sector. However, 2008 and 2009 were not as successful as the previous years, e.g. the turnover of the co-op in the first half of 2009 amounted to only $40 \%$ of the similar period in 2008. They expected a turnover of about HUF 4 billion in 2009, which is only half of the result in 2007. The major problems were connected to liquidity: some members did not sell their products to the co-operative, but tried to sell them on spot for immediate cash. Such short-term thinking and bypassing the co-operative route damaged the marketing channels of the co-op. The co-op had 776 owner-members in July 2009.

The success story of Mórakert Co-operative was partly due to the friendly and supportive approach of the local authority, the various sources of capital derived from funds for development, and above all, the trust and loyalty within the co-operative. However, as the co-operative got bigger, and because of the liquidity problems arising from the economic and financial crisis of 2008, loyalty and trust have become very sensitive issues. The president and the new managing director had to personally approach all of the members in order to ensure that they voted for the necessary changes at the assembly of delegates in March 2009 
(Szabó 2011). As the president of the Mórakert Co-op said: "The retrieval of trust is a matter of money" (Hódi 2009).

The most important effects of the liquidity crisis were two-fold:

1. Huge delays in payments to members and other suppliers (2 billion HUF),

2. Loans mainly for development (1 billion HUF).

Financial solutions to this liquidity problem in July 2009 came from four sources: a loan from the local authority, members' contributions in different ways, state intervention through DATÉSZ Zrt. (private joint stock company) and restructuring of the co-operative into a "forprofit" organisation (to get reserves and savings in order to finance their development) including a cost saving plan and changes in the management. However, in a next stage, the co-operative faced a number of additional liquidity problems, decreasing turnover and organisational issues. At the end of 2010 it had a debt of HUF 3.6 billion (of which HUF 1.1 billion towards members-producers). The co-operative is under bankruptcy protection since 2010 and is very close to ceasing to exist as a co-op. As of January 2012, it is not yet sure what kind of integration form will be established on the basis of the huge real estate (processing line, cold storage depots etc.) which was partly financed from EU support (Szabó 2010; 2011).

\section{Theoretical considerations}

The recent co-operative literature emphasizes the following main incentives for the establishment of co-operatives as a form of vertical integration (VI). First, co-operatives can traditionally provide access to, and secure markets for the long term, therefore giving protection for independent farmers against the large commercial and/or industrial companies. They can also carry out services otherwise not available to producers, or accessible at only very high costs. Second, co-operatives build up countervailing power, and above certain economies of scale, they act as competitive yardsticks for non-co-operative, conventional firms (CF). Third, in some cases co-operatives can increase technological and market efficiency and carry out activities with a higher added value. Fourth, co-operatives can decrease and internalize transaction (e.g. information) costs, with a better flow of information on consumer demand, by creating a closer proximity between consumers and farmers, and 
with a unified decision making between two or more levels of the marketing channel. The co-operative can also decrease both economic and technological uncertainties therefore decrease TCs. Using a co-operative as a governance structure also helps avoiding (ex post) hold-up problems in the case of perishable products and different types of asset specificities. Finally, co-operatives can increase the members' income by diminishing transaction and production costs, and by reimbursing the surplus made at another level of the marketing channel to the members. We may conclude that co-operatives can reduce TCs in several ways. Transaction costs economics emphasises the role of asset specificity, uncertainty and the frequency in inter firm relationships. Because our empirical analysis concentrates only on one cooperative active in the fruit and vegetables sectors, we assume that there are no significant and systematic differences among farmers in terms of frequency and uncertainty of their transactions. Thus, our research focuses on the role of asset specificity in relationships between farmers and the cooperative.

Moreover, the previous literature on governance structures in agri-food chains implicitly assumes specialised farms in their investigations. But the existence of multiproduct farms may affect the form of vertical coordination. Thus, we also investigate the effects of production diversification of farms on their decision to sell products via co-operative.

There are several non-economic considerations, which can also be important for the successful development of co-operatives (Hakelius 1996). First, co-operatives can be considered as "organised trust", which may affect the success or failure of a co-operative. Second, the social and informal network of members or potential members is also relevant as a determining factor in decreasing transaction costs and in the process of establishing and running the activity of a co-operative. Better knowledge and confidence (Røkholt 1999) among members is vital to how co-operatives can be highly efficient in terms of the management of human relations, despite lacking the necessary capital to invest.

The following specific hypotheses based on these preceding theoretical considerations will be tested.

- H1: Asset specificity. The share of the co-operative in selling a farmer's product increases with the value of relationship-specific investments. 
- H2: Complexity. Product complexity and product diversification make searching and establishing new partners lengthy, leaky and expensive. Thus, the share of cooperative in marketing the produce will increase with number of products.

- H3: Reputation. It is expected that reputation has a positive effect on the share of the co-operative in selling products.

- H4: Bargaining power. Farmers with stronger bargaining power sell less via a cooperative.

Therefore, the theoretical model is the following:

Co-operative share $=\beta_{0}+\beta_{1}$ Asset specificity $+\beta_{2}$ Complexity $+\beta_{3}$ Reputation + $\beta_{4}$ Bargaining)

The expected signs of the variables are as follows:

$\beta_{1}>0, \beta_{2}>0, \beta_{3}>0$ and $\beta_{4}<0$.

\section{Survey design}

The questionnaire was prepared in consultation with the management of Mórakert Cooperative. 136 questionnaires were distributed, but after cleaning the data, the total number of observations for analysis was reduced to 107. Table 1 and Table 2 present the descriptive statistics identifying the average cooperative members' profile and their production structure. In order to facilitate the comparison across the different variables, we use the coefficient of variation, defined as the ratio of standard deviation to the mean instead of simple standard deviation.

The average co-operative member's farm size is 15 hectares of land, whilst $30 \%$ of them rent extra land as well. The coefficient of variation (2.63) and the maximum and minimum values corresponding to the total land used emphasise the homogeneity of the producers. The second row of Table 1 shows the group of producers using extra land being rather heterogeneous, renting small plots (4.6 hectares on average, with 4.29 coefficient of variation). $95 \%$ of members use family labour, whilst 36\% employ paid labour (1.3 people on average) as well. In line with the farm size indicators discussed above, the coefficient of variation of paid labour is also rather high (with larger farms employing more paid labour, 
maximum 15 people). Turning to the average age (46 on average, the youngest member is 22 , the oldest 68 ), the group is more homogeneous with a low coefficient of variation.

Table 1. Profile of co-operative members

\begin{tabular}{lrrrr}
\hline Indicators & \multicolumn{1}{c}{ Mean } & Coefficient of variation & Min. & Max. \\
\hline Total land (ha) & 15.3 & 2.69 & 0 & 350 \\
Land rented (ha) & 4.6 & 4.29 & 0 & 150 \\
Full time family labour (person) & 2.5 & 0.89 & 0 & 21 \\
Paid labour (person) & 1.3 & 2.06 & 0 & 15 \\
Age (years) & 45.7 & 0.21 & 22 & 68 \\
Education (1 lowest, 9 highest) & 3.6 & 0.35 & 1 & 8 \\
\hline
\end{tabular}

Source: Own estimations based on the survey

Table 2. Production structure and the link with the cooperative

\begin{tabular}{|c|c|c|c|c|}
\hline Indicators & Mean & $\begin{array}{l}\text { Coefficient of } \\
\text { variation }\end{array}$ & Min. & Max. \\
\hline Vegetable varieties produced & 3.3 & 0.68 & 0 & 12 \\
\hline Fruit varieties produced & 0.4 & 2.26 & 0 & 5 \\
\hline Co-op membership (years) & 4.6 & 0.48 & 0.5 & 11 \\
\hline $\begin{array}{l}\text { Share of vegetable production sold through co- } \\
\text { op }(\%)\end{array}$ & 69.0 & 0.49 & 0 & 100 \\
\hline $\begin{array}{l}\text { Share of fruit production sold through co-op } \\
(\%)\end{array}$ & 14.2 & 2.24 & 0 & 100 \\
\hline $\begin{array}{l}\text { Share of potato production sold through co-op } \\
(\%)\end{array}$ & 30.3 & 1.36 & 0 & 100 \\
\hline
\end{tabular}

Source: Own estimations based on the survey

The lower coefficient of variation indicators in Table 2 suggest that the production structure and the importance of cooperative for the members are more homogenous than the average member's profile. $85 \%$ of those interviewed produce vegetables (on average 3 varieties), whilst $22 \%$ produce fruits (on average 2 varieties). The largest share of production is sold through the cooperative for vegetables (69 per cent), with a low variation across members. Finally, the newest cooperative members joined a year ago, whilst some were present from the beginning. On average, members joined the cooperative 4 years ago. 


\section{Results}

The empirical analysis is conducted in two stages. First, we focus on the importance of various factors in the choice of the co-operative, employing multivariate statistical analysis. Second, we investigate the share of co-operative in the selling of various products applying transaction costs economics framework.

\subsection{Reasons for choice of the co-operative}

The respondents sold $59 \%$ of vegetables, $21 \%$ of fruits and $33 \%$ of potatoes via Mórakert cooperative. Thirty four percent of farmers sold their output to co-operative only, $50 \%$ sold to between two and six buyers, the remainder sold to more than ten buyers. The majority of respondents are individual farms or family farms (97\%), the remainder are partnerships and co-operatives. Thirty four percent of farmers sell only one product and $39 \%$ sell at least five products. Thirty three percent of individual and family farms sell only one product.

The theme concerned with potential benefits of co-operative membership employed a 13item scale that measured the importance of these features in a co-operative choice context (1 $=$ not at all important, $7=$ very important). Figure 1 shows the importance in descending order attached by producers to various marketing factors for sales through the co-operative. The most important factors for selling via the co-operative are quantity, existence of contract, flexibility and trust. Interestingly, habit, price premium, speed of payment and bargaining power issue are unimportant factors. Furthermore, services (input finance, delivery) provided by the co-operative are also not too important factors for farmers.

Figure 1: Importance of various factors in choosing the co-operative (1 - not important; 7 very important) 


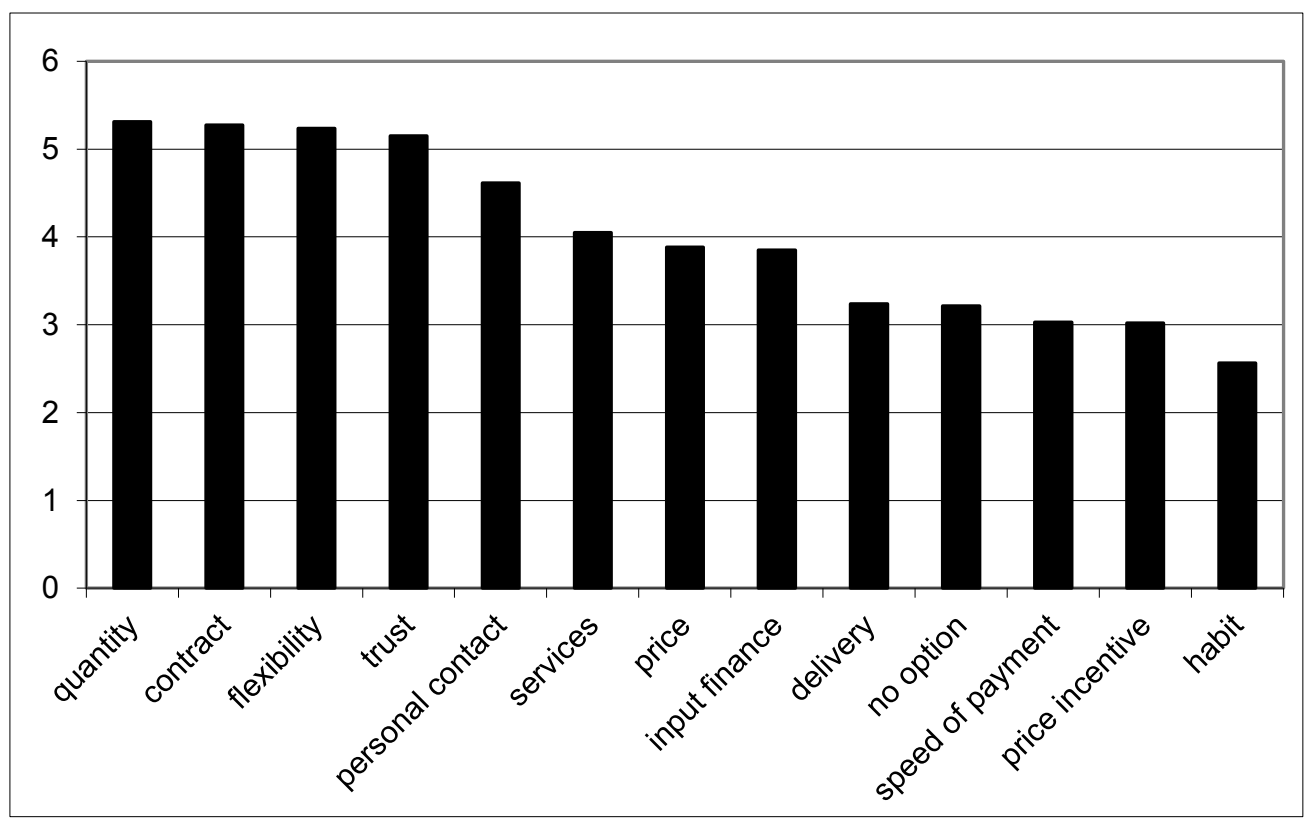

Source: Own estimations based on the survey

We apply canonical correlation analysis to determine the effects of producers' links to cooperative on their perception of benefits from the cooperative. The links of producers to the cooperative are specified as the set of dependent variables, while farmers' rating on factors as a reason to sell through the cooperative are designated as the set of independent variables. We focus only on the most important factors identified by farmers as a reason to sell their products via cooperative. The seven variables resulted in a 13-to-1 ratio of observations to variables exceeding the thumb rule of ten observations per variable (Hair et al. 1998).

Our estimations produced 2 canonical functions with their canonical correlations presented in Table 3. The first and second canonical correlations were 0.44 , and 0.35 , respectively. The $\mathrm{F}$ value of canonical functions revealed that the significance of both canonical functions exceeds the critical value at the 0.10 level. Multivariate test statistics also supported that the two functions fit the data well. The use of a single criterion to decide on whether or not a canonical function should be included in the interpretation is so restrictive that the redundancy index needs to be examined in addition to the level of significance. It is important to interpret only those canonical functions that explain a large proportion of independent variables. 
Table 3. Measures of overall model fit and multivariate tests of significance

\begin{tabular}{llll}
\hline Canonical function & Canonical correlation & F & P value \\
1 & 0.440 & 2.269 & 0.007 \\
2 & 0.345 & 1.940 & 0.083 \\
Tests of significance of all canonical correlations & & \\
& Statistic & F & P value \\
Wilks' lambda & 0.709 & 2.269 & 0.007 \\
Pillai's trace & 0.313 & 2.281 & 0.006 \\
Lawley-Hotelling trace & 0.376 & 2.256 & 0.007 \\
Roy's largest root & 0.240 & 2.957 & 0.008
\end{tabular}

Source: Own estimations based on the survey

Table 4 summarises the redundancy index analysis for reasons of choice of cooperative marketing. The results indicate that total redundancy index was 0.15 , meaning that $15 \%$ of the variance in choice related variables set was explained. More specifically, the first canonical function explained $41.3 \%$, whiles the second $35.3 \%$ of total redundancy. In other words, the two functions together contributed most to the total redundancy. The findings from both statistical significance tests and the redundancy analysis indicate that both canonical functions should be interpreted as the solution. In sum, there exists a strong relationship between the farmers' links to cooperative and their perception on the potential reasons to join to the cooperative.

Table 4. Canonical redundancy index analysis

\begin{tabular}{lllll}
\hline Canonical function & $\begin{array}{l}\text { Variance extracted in } \\
\text { trade variables }\end{array}$ & $\begin{array}{l}\text { Canonical } \\
\mathrm{R}^{2}\end{array}$ & $\begin{array}{l}\text { Redundancy } \\
\text { index }\end{array}$ & $\begin{array}{l}\text { Proportion of } \\
\text { redundancy (\%) }\end{array}$ \\
1 & 0.117 & 0.194 & 0.081 & 41.3 \\
2 & 0.115 & 0.119 & 0.069 & 35.3 \\
\hline
\end{tabular}

Source: Own estimations based on the survey

Table 5 presents the standardized canonical coefficients for the first two dimensions across both sets of variables. For the links with cooperative variables, the first canonical dimension is strongly influenced by both the total share of selling via the co-operative (0.83) and years of membership (-0.80). Interestingly, among independent variables trust and personal contact have high negative coefficients, whilst among the benefits from co-operative price and quantity positively related to the links with cooperative. On the second function, the highest 
coefficient was the year of membership. Among independent variables, the existence of contract has the highest coefficient (0.94), followed by a high negative coefficient of trust (0.59). Hence, the year of membership was positively affected by the contract, but was hampered by trust.

Table 5. Standardized Canonical Coefficients

\begin{tabular}{lcc}
\hline Variables & \multicolumn{2}{l}{ Dimension } \\
& 1 & 2 \\
Dependent variables: Links with cooperative & & \\
Years of membership & -0.798 & 0.655 \\
Total share of selling via cooperative & 0.833 & 0.609 \\
Independent variables: Reasons of choice & & \\
Quantity & 0.503 & 0.280 \\
Contract & 0.094 & 0.938 \\
Flexibility & 0.078 & -0.209 \\
Trust & -0.471 & -0.591 \\
Personal contact & -0.754 & 0.103 \\
Price & 0.577 & -0.538 \\
Services & 0.469 & 0.112 \\
\hline
\end{tabular}

Source: Own estimations based on the survey

\subsection{The share of co-operative selling}

In this section we test the hypotheses of transaction cost economics related to the share of products marketed by the co-operative. Our variables are the following:

- Dependent variable: SHARE, ranging between 0 and 100 per cent.

- Explanatory variables:

○ Physical asset specificity. Horticultural production's physical asset specificity is captured by two variables: 1) area of plastic tunnel (PLASTIC); 2) irrigated area (IRRIGATED).

- Human asset specificity measure as: 1) age of farmers (AGE), and 2) farmers' highest level of education (EDUCATION).

- Finally, we add the length of co-op membership (in years), as a proxy for relation specific asset (MEMBER YEAR). Being a cooperative member for longer may imply a positive expectation on benefits from cooperative. 
○ Complexity and diversification. Production diversity is measured by the number of products in horticultural production (DIVERSIFICATION).

- Reputation. It is difficult to quantify reputation in a postal questionnaire; we used two proxies for measuring reputation. We asked about the reasons for selling product via co-operative. The respondents evaluated the importance of specific factors, including trust (TRUST) and personal contact (PCONTACT) on a seven points-scale.

- Bargaining power. We apply two proxies for bargaining power: 1) number of buyers (BUYERS), and 2) farmers who have no other option to sell their product (NO OPTION)

We estimate our model on total sales separately for each product. We report only the best results in terms of our a priori expectations and statistical significance. Table 6 shows our estimations for total sales. Interestingly, results indicate that asset specificity variables have been significant and unexpected. The DIVERSIFICATION and MEMBER YEAR variables have expected signs but they are not significant. This suggests that farmers producing more products sell more via co-operative. The reputation variable (TRUST) is not significant. Finally, the negative and significant coefficient of BUYERS suggests that farmers with larger bargaining power sell fewer products via cooperative.

Table 6. Tobit regression results for the share of co-operative selling in total sales

\begin{tabular}{ll}
\hline & \multicolumn{1}{c}{ Share of the co-operative } \\
IRRIGATION & $-0.000^{*}$ \\
EDUCATION & $-0.036^{* *}$ \\
DIVERSIFICATION & $0.052^{* * *}$ \\
TRUST & 0.002 \\
MEMBER YEAR & 0.008 \\
BUYERS & $-0.003^{* *}$ \\
CONSTANT & $0.275^{* *}$ \\
Pseudo R2 & 0.418 \\
\hline \multicolumn{2}{c}{ Note: ${ }^{*} \mathrm{p}<0.1 ; * * \mathrm{p}<0.05 ; * * \mathrm{p}<0.01$} \\
\multicolumn{2}{c}{ Source: Own estimations based on the survey }
\end{tabular}

The estimated coefficients of a Tobit regression for vegetables are presented in Table 7 . The estimations indicate that asset specificity variables are significant, but have unexpected sign. 
The reputation variable (TRUST) is significant with expected signs. It indicates that the growing reputation leads to larger share products being sold by the co-operative. The complexity variable (DIVERSIFICATION) has expected signs with significance. This suggests that farmers producing more products sell more via the co-operative. Similarly to the previous estimation, the coefficient of BUYERS is significant implying that farmers with stronger bargaining power use the cooperative less.

Table 7. Tobit results for the share of co-operative selling in total vegetable sales

\begin{tabular}{ll}
\hline & Share of co-operative \\
IRRIGATION & $-0.001^{*}$ \\
EDUCATION & $-0.122^{* * *}$ \\
DIVERSIFICATION & $0.033^{* *}$ \\
TRUST & $0.047^{*}$ \\
MEMBER YEAR & $0.034 *$ \\
BUYERS & $-0.007 * * *$ \\
CONSTANT & $0.744 * * *$ \\
Pseudo R & 0.3571 \\
\hline \multicolumn{2}{c}{ Note: $* \mathrm{p}<0.1 ; * * \mathrm{p}<0.05 ; * * * \mathrm{p}<0.01$}
\end{tabular}

Source: Own estimations based on the survey

The fruit model yields less promising results (Table 8). The estimations indicate that asset specificity variables are not significant with an unexpected sign for IRRIGATION and the expected sign for EDUCATION. The complexity variable (DIVERSIFICATION) is significant with expected sign. This suggests again that farmers with wider product assortments sell more via co-operative.

Table 8. Tobit results for the share of co-operative selling in total fruit sales

\begin{tabular}{ll}
\hline & Share of co-operative \\
IRRIGATION & -0.000 \\
EDUCATION & 0.162 \\
DIVERSIFICATION & $0.305 * * *$ \\
PCONTACT & -0.185 \\
MEMBER YEAR & 0.031 \\
BUYERS & 0.009 \\
CONSTANT & $-2.523 *$ \\
Pseudo ${ }^{2}$ & 0.2015 \\
\hline
\end{tabular}




$$
\text { Note: }{ }^{*} \mathrm{p}<0.1 ; * * \mathrm{p}<0.05 ; * * * \mathrm{p}<0.01
$$

Source: Own estimations based on the survey

Estimations for potato sales are presented in Table 9. The asset specificity variables have unexpected signs and they are also significant. We find that complexity is positively and significantly related to the share of co-operative selling. The reputation (PCONTACT) variable is not significant with an unexpected sign. It indicates that trust yields a larger share of co-operative in selling of products. The bargaining power variables have expected signs without significance.

Table 9. Tobit results for the share of co-operative selling in total potato sales

\begin{tabular}{ll}
\hline & Share of co-operative \\
IRRIGATION & $-0.007^{*}$ \\
EDUCATION & $-0.274^{*}$ \\
DIVERSIFICATION & $0.286^{* * *}$ \\
PCONTACT & -0.000 \\
MEMBER YEAR & $0.165^{*}$ \\
NO OPTION & -0.114 \\
CONSTANT & -0.209 \\
Pseudo $\mathrm{R}^{2}$ & 0.2430 \\
\hline$* * * p<0.01$ &
\end{tabular}

Note: $* \mathrm{p}<0.1 ; * * \mathrm{p}<0.05 ; * * * \mathrm{p}<0.01$

Source: Own estimations based on the survey

\section{Discussion and conclusions}

In this paper we analyzed the potential benefits and costs of the marketing cooperatives in Hungary, employing a transaction cost economics framework. The results presented add to the literature on the marketing cooperatives in transition agriculture. Although there are similar co-operatives in the Hungarian horticultural sector, our example, the Mórakert cooperative was the most successful. We found that the quantity, the existence of contract, flexibility and trust are the most important factor for farmers when deciding to sell their product via the co-operative. It is noteworthy that direct benefits from the cooperative, including the speed of payment, price incentives, delivery, input finance play less important roles. Canonical correlation shows a strong relationship between farmers' links with the co- 
operative and the most important reasons for choosing to join to the co-operative and sales to the co-operative.

In the next step we focused exclusively on the sales to the cooperative, introducing additional variables based on transaction cost theory. Tobit estimations yielded rather diverse results for each product groups with respect to our a priori theoretical expectations. We obtained good results for vegetable produce. One of the reasons may be that vegetable products are the most important items for farmers selling via a co-operative. The hypothesis on the positive relationship between asset specificity and the share of co-operative selling is not confirmed. These results can be explained partly by the weakness of usual proxies for measuring physical and human asset specificity. The irrigation and education variables may have rather broader relevance especially in terms of access to better factor endowments and/or technology of farms. Thus, we can argue that farms with better technology are likely able to establish business relationships outside of the co-operative, implying larger farm size and more bargaining power for them. Consequently, these farms likely sell less product groups to the co-operative. Our results provide more support to the positive link between diversification and the share of co-operative selling. Data also reveals that farmers in our sample are less specialised, their risk management is based mainly on the traditional multiproduct peasant farm strategy. Surprisingly, we found that reputation has a positive effect upon total sales to the co-operative for vegetables only. This outcome can be explained by the fact of being a member of the co-operative implies a strong commitment to the cooperative. Farmers with longer periods of membership sell more products via the cooperative. Finally, the bargaining power of farms is negatively related to the share of cooperative selling.

The results also shed light on some of the co-ops' limitations. Whilst the co-operative successfully integrates the small scale farms into the globalised market, larger and probably more efficient farms sell just a smaller fraction of their product to the cooperative causing difficulties to fulfil quantity requirements of the cooperative's contract with its buyers.

The limitations of our research are inherent in the case study approach. Our results cannot be generalised across all cooperatives in Hungary due to differences in geographical location 
and commodity handled. Thus, further research is needed to clarify the costs and benefits of marketing cooperatives.

\section{References}

Boger, S. (2001): Quality and contractual choice: a transaction cost approach to the Polish hog market, European Review of Agricultural Economics 28: 241-261.

Boger, S. - Beckman, V. (2004): Courts and contract enforcement in transition agriculture: theory and evidence from Poland, Agricultural Economics 31: 251-263.

Dries, L. - Swinnen, J. F. M. (2004): Foreign direct investment, vertical integration and local suppliers: evidence from the Polish dairy sector, World Development 32: 1525-1544.

Forgács, C. (2008): Leadership and Importance of Social Capital in Cooperatives during Transition: A Case Study of Two Cooperatives, Journal of Rural Cooperation 35(2):5772.

Gardner, B. - Lerman, Z. (2006): Agricultural Cooperative Enterprise in the Transition from Socialist Collective Farming, Journal of Rural Cooperation 34. 1-18.

Gorton, M. - Dumitrashko, M. - White, J. (2006): Overcoming supply chain failure in the agri-food sector: A case study from Moldova, Food Policy 31: 90-103.

Gow, H. R. - Streeter, D. H. - Swinnen, J. F. M. (2000): How private contract enforcement mechanisms can succeed where public institutions fail: the case of Juhocukor a.s., Agricultural Economics 23: 253-265.

Hair, J. F. - Anderson, R. E. - Tatham, R. L. - Black, W. C. (1998): Multivariate Data Analysis. New Jersey: Prentice Hall

Hakelius, K. (1996): Cooperative Values - Farmers' Cooperatives in the Minds of the Farmers. Swedish University of Agricultural Sciences, Uppsala, Dissertations 23

Hanf, J. - Török, T. (2009): Are Co-ops a Way to integrate small Farmers in Supply Chain Networks?, Journal of Rural Co-operation 37(1): 20-31. 
Hendrikse, G. W. J. - Veerman, C. P. (2001): Marketing co-operatives and financial structure: a transaction costs economic analysis, Agricultural Economics 26: 205-216.

Hódi, P. (2009): Interview (President of Board of Directors of Mórakert Co-operative), July 2009. (in Hungarian)

Røkholt, P. O. (1999): Strengths and weaknesses of the co-operative form; A Matter of Perspective and Opinion. Paper presented at the ICA International Research Conference, Quebec, 28-29 August 1999.

Szabó, G. G. (2010): The Importance and Role of Trust in Agricultural Marketing CoOperatives, Studies in Agricultural Economics 112: 5-22.

Szabó, G. G. (2011): Leading producer-owned marketing organisations in transition country: Two case studies from Hungarian agribusiness. In: Baourakis, G. - Konstadinos Mattas, K. - Zopounidis, C. - van Dijk, G. (eds.): A resilient European food industry in a challenging world, New York: Nova Science Publishers, pp. 337-358.

Williamson, O. E. (1985): The Economic Institutions of Capitalism. New York: Free Press. 